\title{
LOCAL COMMUNITY SUPPORT FOR THE TRANSFORMATION OF A HISTORICAL BUILDING INTO A HOTEL: case of the Corupá Seminary/SC
}

\author{
Jaqueline de Souza Brognia; \\ Samara Jane Effting Vieirab; \\ Pablo Flôres Limbergerc; \\ Marcos Arnhold Júniord
}

\begin{abstract}
As part of the built historical and cultural heritage of Corupá/SC, the structure of the Sacred Heart of Jesus Seminary [Seminário Sagrado Coração de Jesus] has great tourism potential directly linked to nature, leisure, history and religion. This study investigates the support of the local community for the development of tourism in the city of Corupá and the possibility of turning the historical Seminary building into a hotel. To achieve this objective, a quantitative methodology was used to measure the residents' views on the positive and negative impacts of tourism, and on the introduction of a new hotel in the town. Among the main results, it was found that the local community has a desire to participate, contribute, and give their opinions about project, as they believe that tourism has positive impacts. They also believe that the current structure of the Corupá Seminary, which is lying dormant, is a waste, and that a building that is part of the cultural and historical heritage should not have its use restricted.
\end{abstract}

\section{KeYWORDS}

Hotel

Local community support

Historical Heritage

Religious Tourism 


\section{INTRODUCTION}

Religious buildings, including convents and seminaries have, since their foundation, been influential and important in sociological, economic and urban transformations. Besides the monumental dimensions and artistic value, they portray social and economic changes throughout history (Mirrado, 2016). But many of the original functions of these spaces are now obsolete, and they are looking for other resources and uses that will ensure their autonomy (Aspres, 2017).

These places have great historical and cultural value, in addition to their symbolic value, characterized by religiosity (Aulet, Mundet, \& Vidal, 2017). Religious buildings, with their unique characteristics, have generated strong potential for tourism (Juravle \& Spãtaru, 2016), as faith as their strong ally, motivating people to learn more about their religious history and culture (De La Torre, Naranjo, \& Cardenas, 2012; Ferreira \& Santos, 2010; lapichino, 2010; Tendeiro, 2010). Studies such as that of Aspres (2017) have analyzed the transformations taking place in religious spaces, according to the criteria of: authenticity, identity, operative action and function, in monuments whose original function is now obsolete, but that have adapted to other uses to ensure their autonomy.

Founded by German, Italian and Polish colonists, the Corupá region of Santa Catarina (SC) is a privileged area for ecotourism. It has a rugged landscape, cut across by many rivers and streams that have resulted in a series of waterfalls, giving the town great tourist potential (Turismo Corupá, 2018). The Sacred Heart of Jesus Seminary is located in the municipality. It is a symbolic building with striking architecture but today, it has fallen into disuse, and there have been studies and projects to turn it into a hotel.

The history of the building goes back to 1929, when the Catholic community of Corupá offered a plot of land to its congregation, which needed to expand its activities. In 1932, with the arrival of the first seminary students, the enterprise was inaugurated, and from the 1960s to the 1980s, the structure, with twenty thousand square meters of built area, was receiving 230 students. The seminary includes a chapel, museum, theater, classrooms, dormitories, games room, wine cellar, library, cafeteria, thematic gardens and sports courts. It is a building of great architectural and historical grandeur, with Germanic influences, and carries a wealth of symbolism related to faith, religion and art. But now, with the decline in the number of students entering the seminary, it no longer serves its original function. Instead, it has become a provincial headquarters and a tourist land- mark for the city, receiving visitors and tourists throughout the year. But even so, much of its structure remains unoccupied (Seminário de Corupá, 2018). Given that tourism has a great potential to affect the lives of the local community (Marzuki, 2012; Andereck \& Nyaupane, 2011), when studying a destination that has a strong heritage culture, $\mathrm{Ng}$ and Feng (2020) found results that indicate that a positive attitude of residents towards tourism has a positive effect on their support for tourism development. Residents with a strong sense of belonging in the tourist location tend to have strong attitudes, both positive and negative, towards tourism. Above all, these residents still exercised great influence in the revitalization of a historic hotel and are fundamental to the transformation and renovation of a space that is considered part of the local heritage (Xie \& Shi, 2018).

Xie and Shi (2018) highlight that the design of a hotel that encompasses heritage requires authenticity and co-creation, and must include at least three stakeholders: the government, community organizations, and the local community. Sometimes, the local residents may feel powerless and excluded from these decisions. Involving them in the process is, therefore, the most innovative way to revitalize and sustain historic hotels, as it creates a new identity for the society. Therefore, understanding the residents and the impacts of tourism on their lives is an indispensable aspect for the success of tourism development in a city (Bimonte \& Faralla, 2016).

\section{Local Community Support for Tourism}

Many surveys have been carried out, seeking to understand the relationship of the local community with the impacts caused and perceived through the development of tourism in their regions. These may be associated with economic, social, environmental or cultural aspects or, in general, how they contribute or not to perceived quality of life of the community (Björk \& Sthapit, 2017; Chi, Cai, \& Li, 2017; Ivlevs, 2017; Almeida -García et al., 2016; Bimonte \& Faralla, 2016; Ozturk, Ozer, \& Çaliskan, 2015 ; Woo, Kim, \& Uysal, 2015; Stylidis et al., 2014; Marzuki, 2012; Andereck \& Nyaupane, 2011; Gursoy \& Rutherford, 2004; Ko \& Stewart, 2002; Yoon, Gursoy, \& Chen, 2001).

In studies such as that of Xie and Shi (2018), residents exerted great influence on the revitalization of a historic hotel and are also fundamental for the transformation and renovation of a space that is considered heritage. Tourism has become one of the main cultural and economic forces in the world today, and has great potential to affect the lives of the residents of a community (Marzuki, 2012; Andereck \& Nyaupane, 2011). Therefore, understanding the resident community's perception of the impacts that tourism has on their daily lives is increasingly important (Milito, 
Marques, \& Alexandre, 2013).

Residents are indispensable for the success of a destination's tourist development, therefore, understanding whether, and how far tourism affects residents' perception of satisfaction of life is a crucial issue (Bimonte \& Faralla, 2016). In short, the relationship between tourism, acceptance and perceptions of the local community is decisive for the hospitality of a place. The tourist looks for a sense of feeling welcome at the destination being visited, and this acceptance comes from the good reception of the host community (Björk \& Sthapit, 2017; Woo, Kim, \& Uysal, 2015; Stilidy et al., 2014). In general, residents who satisfied with their lives support tourism and accept its impacts. Despite perceiving these impacts, residents accept it because they are aware of the benefits that tourism brings to their city (Chi, Cai, \& Li, 2017).

Yoon, Gursoy and Chen (2001) point out that residents would probably support the development of tourism in their city or region, particularly due to the consequent investments in infrastructure that benefits tourists and also the community, such as the introduction or improvement of resort complexes, recreational facilities, hotels, restaurants and new entertainment options. Years later, completing this study, Andereck and Nyaupane (2011) found that residents who perceived higher levels of personal benefits from tourism had more positive attitudes towards tourism, and were more favorable to the development of tourism than those who do not did not feel they had received any benefits from tourism. This is corroborated by $\mathrm{Ng}$ and Feng (2020), who found that residents' positive attitudes towards tourism positively affects their support for tourism development. Marzuki (2012) also found that, in general, residents tended to perceive the benefits of tourism more than the negative impacts.

Ozturk, Ozer and Çaliskan (2015) also investigated local residents' attitudes towards tourism. They suggest that before proposing a development plan for tourism, planners and decision makers need to consider local residents' concerns about environmental, cultural issues, and how the impacts caused by tourism could affect them economically. Xie and Shi (2018) also found that residents are interested in participating in more debates involving the heritage and history of their town or city, particularly when it involves bringing disused buildings to life, and that value identity and connection with the past.

Rasoolimanesh et al. (2019) found, in their research, that some residents who live in the areas around heritage tourism sites may be less inclined to support attempts to preserve local heritage assets, due to the perceived negative impacts that the tourism development could bring. Hartwell et al. (2018) conducted tourism impact studies, and found that the local residents of a destination can perceive how much tourism affects the life of the community, from improvements in quality of life, tourist facilities, attractions and events that residents can also benefit from, as well as increased employment and income opportunities. However, residents also noted negative impacts, such as traffic congestion and rising crime rates. But overall, when the majority of the impacts are positive in the local residents' perception, they will see the improvements in their quality of life and support the development of tourist activity, ensuring more sustainability for the destination. Krippendorf (2001) points out that the local communities living in tourist regions are increasingly feeling antipathy towards tourism as they perceive the negative effects of mass tourism, giving them a sense that their space is being invaded, to the extent that they begin to feel excluded from the environment where they live.

Taking a different perspective, the length of time a person has lived in a town can affect their attitudes towards tourism; it was found that those who have lived in a destination for more than ten years perceived tourism more negatively. These are the profiles that should be given special attention when planning and tourism policies, aiming to improve with these residents, and their attitudes towards tourism (Almeida-García et al., 2016).

In view of these aspects, it is clear that the success of tourism in a destination is generally achieved with the support of local residents, who must be satisfied with their living conditions as a whole, to demonstrate support for this activity and its development (Chi, Cai, \& Li, 2017; Woo, Kim, \& Uysal, 2015). That is why involving residents in decisions related to tourism management is so important. Besides ensuring that the local community understands the importance of tourism for their town, when the residents feel they are part of the decision-making process, they will also be more likely to accept some of the inconveniences that accompany tourism (Almeida-García et al ., 2016; Ozturk, Ozer, \& Çaliskan, 2015).

\section{METHODOLOGICAL ASPECTS}

To achieve the proposed objectives, a quantitative survey was conducted with residents of Corupá, in order to determine the extent to which they support for the development of tourism in the town, as well as their support for the implementation of a new hotel linked to a building of the historical and cultural heritage. The research was divided into two stages. In the first stage, the positive and negative impacts of tourism in 15 variables were measured, following the construct used by Ozturk, Ozer and Çaliskan (2015), with the following dimensions: negative and positive cultural and environmental impacts, crime, and posi- 
tive and negative economic impacts. The second stage, using the construct of Xie and Shi (2018), used 10 variables to measure the impacts of the implementation of a new hotel in the town of Corupá, this new hotel being part of the cultural and historical heritage of the town. Thus, the instrument was composed of 25 variables, which are added to the constructs of Ozturk, Ozer and Çaliskan (2015) and Xie and Shi (2018). Their construction is shown in Table 1, below.

All the scales that measured the construct are based on the metric measure, i.e., interval scales with seven items of the Likert type, ranging from totally disagree to totally agree. An initial filter question was added, as the research focus was only residents of Corupá. At the end of the survey, the socio-demographic data of the interviewees were also verified: sex, age, marital status, and time of residence in the town.

According to IBGE Cidades (2020), the estimated population in 2020 for Corupá is 16,107 inhabitants, with 13,852 residents recorded in the last census, conducted in 2010. For Hair Jr. et al. (1998) there should be 5 to 10 respondents per parameter in the model, and the minimum number of elements that make up the sample should be between 100 and 150 . Thus, with a model of 22 variables, according to Hair Jr. et al. (1998), a sample of between 110 and 220 respondents is recommended. Our research sample was collected nonprobabilistically and by convenience. The data collection was done using Google Form, between March 7 and 30,2019, resulting in a sample of 239 respondents,

Table 1: Construct to measure the impacts of tourism and residents' support for tourism

\begin{tabular}{|c|c|c|}
\hline Factor & Variables & Author \\
\hline $\begin{array}{l}\text { Negative cultural } \\
\text { and environmental } \\
\text { impacts }\end{array}$ & $\begin{array}{l}\text { Q1: Tourism causes difficulties for the local community of Corupá } \\
\text { Q2: Tourists have a negative impact on the lifestyle of the local community } \\
\text { of Corupá } \\
\text { Q3: Tourism destroys the natural environment in Corupá } \\
\text { Q4: Tourism causes pollution in Corupá } \\
\text { Q5: Tourism causes overcrowding in Corupá }\end{array}$ & $\begin{array}{c}\text { Ozturk; Ozer; Çaliskan } \\
(2015)\end{array}$ \\
\hline Crime & $\begin{array}{l}\text { Q6: Tourism causes traffic jams and accidents in Corupá } \\
\text { Q7: Tourism increases crime rates in Corupá } \\
\text { Q8: Tourism increases violence in society in Corupá } \\
\text { Q9: Tourism causes an increase in prostitution in Corupá }\end{array}$ & $\begin{array}{l}\text { Ozturk; Ozer; Çaliskan } \\
\text { (2015) }\end{array}$ \\
\hline $\begin{array}{l}\text { Negative } \\
\text { economic impacts }\end{array}$ & $\begin{array}{l}\text { Q10: Tourism causes an increase in the prices of goods and services in } \\
\text { Corupá } \\
\text { Q11: The general economic condition in Corupá is not good because } \\
\text { of tourism }\end{array}$ & $\begin{array}{l}\text { Ozturk; Ozer; Çaliskan } \\
\text { (2015) }\end{array}$ \\
\hline $\begin{array}{l}\text { Positive } \\
\text { economic impacts }\end{array}$ & $\begin{array}{l}\text { Q12: Tourism attracts more investments to Corupá } \\
\text { Q13: Tourism creates more job opportunities in Corupá }\end{array}$ & $\begin{array}{l}\text { Ozturk; Ozer; Çaliskan } \\
\text { (2015) }\end{array}$ \\
\hline $\begin{array}{l}\text { Positive cultural } \\
\text { and environmental } \\
\text { impacts }\end{array}$ & $\begin{array}{l}\text { Q14: Tourism has a positive impact on the local culture in Corupá } \\
\text { Q15: Tourism increases the number of recreational parks and green areas }\end{array}$ & $\begin{array}{c}\text { Ozturk; Ozer; Çaliskan } \\
(2015)\end{array}$ \\
\hline $\begin{array}{l}\text { Impacts of the } \\
\text { implementation of } \\
\text { a new hotel }\end{array}$ & $\begin{array}{l}\text { Q16: The implementation of a new hotel in Corupá should reflect the feed- } \\
\text { back and comments of the residents. } \\
\text { Q17: The plan for implementing a new hotel in Corupá needs to be better } \\
\text { communicated to the different stakeholders. } \\
\text { Q18: The disused Seminary building in Corupá is a waste. } \\
\text { Q19: Young people, parents and teachers should be encouraged to take part } \\
\text { in the project by submitting their ideas. } \\
\text { Q20: The community should be encouraged to take part in the project by } \\
\text { sending in ideas. } \\
\text { Q21: Better channels need to be established to involve local residents in this } \\
\text { change. } \\
\text { Q22: A building of cultural and historical heritage should have restricted use. } \\
\text { Q23: The plan for implementing a new hotel must be transparent and acces- } \\
\text { sible to the population. } \\
\text { Q24: The historical significance of the Seminary must be assessed by an ex- } \\
\text { pert committee. } \\
\text { Q25: The design of the Corupá Seminary should create a new image and } \\
\text { identity for the city. }\end{array}$ & Xie; Shi (2018) \\
\hline
\end{tabular}


191 of which returned valid questionnaires, i.e., 191 were residents of Corupá.

The data were quantified using the software programs Statistical Package for the Social Sciences (SPSS) and Microsoft Excel. The descriptive results are demonstrated by means of frequencies, percentages, means, standard deviation and variance.

\section{RESULTS}

Based on the sociodemographic data, it was possible to profile the interviewees. Table 2 highlights the characteristics of this sample, divided into sex, age group, marital status and time of residence in the city of Corupá:

As Table 2 shows, the respondent profile is composed mostly of women (61.3\%), predominantly aged between 25 and 39 years (45.5\%), married or living in a stable union (63.9\%), and living in Corupá for 25 years or more $(49.7 \%)$. Tables 3 to 8 show the averages of the constructs that built this study:

In Table 3, the construct of negative cultural and environmental impact is measured, which presented an average dimension of 1.99, considered low on the Likert scale, which was from 1 to 7 points. This shows that in general, residents do not agree with the statements that tourism causes difficulties for the community, or that it destroys the natural environment, or causes pollution or overcrowding in the city. This result differs from that found by Krippendorf (2001), that residents increasingly present feelings against tourism be-

Table 2: Sample characteristics

\begin{tabular}{|c|c|c|c|}
\hline \multicolumn{2}{|c|}{ Feature } & Frequency & Percentage \\
\hline \multirow{3}{*}{ Sex } & Male & 74 & $38.7 \%$ \\
\hline & Female & 117 & $61.3 \%$ \\
\hline & Total & 191 & $100 \%$ \\
\hline \multirow{6}{*}{$\begin{array}{c}\text { Age } \\
\text { Range }\end{array}$} & Under 15 years & 1 & $0.5 \%$ \\
\hline & 15 to 24 years & 42 & $22 \%$ \\
\hline & 25 to 39 years & 87 & $45.5 \%$ \\
\hline & 40 to 55 years & 47 & $24.6 \%$ \\
\hline & 56 years or older & 14 & $7.3 \%$ \\
\hline & Total & 191 & $100 \%$ \\
\hline \multirow{5}{*}{$\begin{array}{l}\text { Marital } \\
\text { status }\end{array}$} & Single & 58 & $30.4 \%$ \\
\hline & $\begin{array}{l}\text { Married/Stable } \\
\text { Union }\end{array}$ & 122 & $63.9 \%$ \\
\hline & $\begin{array}{l}\text { Separated/ } \\
\text { Divorced }\end{array}$ & 8 & $4.2 \%$ \\
\hline & Widower & 3 & $1.6 \%$ \\
\hline & Total & 191 & $100 \%$ \\
\hline
\end{tabular}

\begin{tabular}{|c|c|c|c|}
\hline \multicolumn{2}{|c|}{ Feature } & Frequency & Percentage \\
\hline \multirow{7}{*}{$\begin{array}{l}\text { Time of } \\
\text { residence } \\
\text { in Corupá }\end{array}$} & $\begin{array}{l}\text { Less than } 5 \\
\text { years }\end{array}$ & 12 & $6.3 \%$ \\
\hline & 5 to 9 years & 18 & $9.4 \%$ \\
\hline & 10 to 14 years & 14 & $7.3 \%$ \\
\hline & 15 to 19 years & 17 & $8.9 \%$ \\
\hline & 20 to 24 years & 35 & $18.3 \%$ \\
\hline & $\begin{array}{l}25 \text { years or } \\
\text { more }\end{array}$ & 95 & $49.7 \%$ \\
\hline & Total & 191 & $100 \%$ \\
\hline
\end{tabular}

Source: Prepared by the authors (2019).

cause they perceive the negative impacts and the feeling that their space is being invaded.

Understanding this relationship between residents and tourism is crucial, as according to Bimonte \& Faralla (2016), residents are indispensable for the success of a destination's tourism development. Therefore, it is of paramount importance to understand whether and

Table 3: Averages of the construct Negative cultural and environmental impact

\begin{tabular}{l|c|c|c|c}
\hline \multicolumn{1}{c|}{ Variable } & $\begin{array}{c}\text { Ave- } \\
\text { rage }\end{array}$ & $\begin{array}{c}\text { Standard } \\
\text { Devia- } \\
\text { tion } \\
\text { (p) }\end{array}$ & $\begin{array}{c}\text { Variance } \\
\text { (P) }\end{array}$ & $\begin{array}{c}\text { Average } \\
\text { Dimen } \\
\text { sion }\end{array}$ \\
\hline $\begin{array}{l}\text { Q1:Tourism } \\
\text { causes diffi- } \\
\text { culties for } \\
\text { the local } \\
\text { community } \\
\text { of Corupá. }\end{array}$ & 1,723 & 1.4944 & 2,233 & \\
\hline $\begin{array}{l}\text { Q2: Tourists } \\
\text { have a nega- } \\
\text { tive impact } \\
\text { on the life- } \\
\text { style of the } \\
\text { local com- } \\
\text { munity of } \\
\text { Corupá. }\end{array}$ & 1,775 & 1.5378 & 2,365 & \\
\cline { 1 - 2 } $\begin{array}{l}\text { Q3: Tourism } \\
\text { destroys the } \\
\text { natural envi- } \\
\text { ronment in } \\
\text { Corupá. }\end{array}$ & 2,168 & 1.6680 & 2,782 & \\
\hline $\begin{array}{l}\text { Q4: Tourism } \\
\text { causes pollu- } \\
\text { tion in } \\
\text { Corupá. }\end{array}$ & 2,272 & 1.6220 & 2,631 & \\
\cline { 1 - 2 } $\begin{array}{l}\text { Q5: Tourism } \\
\text { causes over- } \\
\text { crowding in } \\
\text { Corupá. }\end{array}$ & 2,016 & 1.7486 & 3,058 & \\
\cline { 1 - 2 } & & & & \\
\end{tabular}

Source: Prepared by the authors (2019).

how tourism affects resident's perceptions of satisfaction with life. This result also corroborates the research by $\mathrm{Ng}$ and Feng (2020), who point out that the residen- 
ts' positive attitude towards tourism positively affects their support for tourism development.

Table 4 measured the construct Crime, which also had a low overall average (1.93) and low standard deviation, that is, residents did not agree that tourism brings traffic jams and accidents to the city, increases crime rates, or increases violence and prostitution. According to Almeida-García et al. (2016) and Ozturk, Ozer, \& Çaliskan (2015) it is important that residents feels they are part of the decision-making process, because if changes are to be made, they will be more likely to accept the inconveniences that come with tourism.

Among the constructs that measured negative impacts, in Table 5, the negative economic impact was the one with the highest average (2.44), but was considered very low. Which means that residents do not agree with the claims that tourism causes price increases and is harmful for the town's economy. This is corroborated by Ozturk, Ozer and Çaliskan (2015), who state that in the economic sector, tourism attracts more investments and creates more job opportunities.

Table 4: Averages of construct Crime

\begin{tabular}{l|c|c|c|c}
\hline \multicolumn{1}{c|}{ Variable } & $\begin{array}{c}\text { Ave- } \\
\text { rage }\end{array}$ & $\begin{array}{c}\text { Standard } \\
\text { Deviation } \\
\text { (p) }\end{array}$ & $\begin{array}{c}\text { Variance } \\
\text { (P) }\end{array}$ & $\begin{array}{c}\text { Avera- } \\
\text { ge } \\
\text { dimen- } \\
\text { sion }\end{array}$ \\
\hline $\begin{array}{l}\text { Q6: Tourism } \\
\text { causes traf- } \\
\text { fic jams and } \\
\text { accidents in } \\
\text { Corupá. }\end{array}$ & 1,921 & 1.6056 & 2,578 & \\
\hline $\begin{array}{l}\text { Q7: Tourism } \\
\text { increases } \\
\text { crime rates } \\
\text { in Corupá. }\end{array}$ & 2,220 & 1.8104 & 3,278 & \\
\hline $\begin{array}{l}\text { Q8: Tourism } \\
\text { increases } \\
\text { violence in } \\
\text { society in } \\
\text { Corupá. }\end{array}$ & 1,916 & 1.4950 & 2,235 & \multirow{2}{*}{1.9346} \\
\cline { 1 - 2 } $\begin{array}{l}\text { Q9: Tourism } \\
\text { causes an } \\
\text { increase in } \\
\text { prostitution } \\
\text { in Corupá. }\end{array}$ & 1,681 & 1.3602 & 1.850 & \\
\cline { 1 - 1 }
\end{tabular}

Source: Prepared by the authors (2019).

In general, the three dimensions analyzed so far, presented in Tables 4, 5 and 6, verify the negative impacts of tourism in the town, and are evaluated with low averages. In other words, i.e., residents do not feel these impacts affect their lives. However, it is worth emphasizing the importance of the resident's interaction in decision-making so that they feel engaged in the process and even if there is some negative impact they will be

Table 5: Averages of the construct Negative economic impacts

\begin{tabular}{l|c|c|c|c}
\hline Variable & $\begin{array}{c}\text { Ave- } \\
\text { rage }\end{array}$ & $\begin{array}{c}\text { Standard } \\
\text { Deviation } \\
\text { (p) }\end{array}$ & $\begin{array}{c}\text { Varian- } \\
\text { ce } \\
\text { (P) }\end{array}$ & $\begin{array}{c}\text { Average } \\
\text { dimen- } \\
\text { sion }\end{array}$ \\
\hline $\begin{array}{l}\text { Q10: Tour- } \\
\text { ism causes } \\
\text { an increase } \\
\text { in the pric- } \\
\text { es of goods } \\
\text { and services } \\
\text { in Corupá. }\end{array}$ & 3,068 & 2.1202 & 4,495 & \\
\hline $\begin{array}{l}\text { Q11: The } \\
\text { general } \\
\text { economic } \\
\text { condition in } \\
\text { Corupá is } \\
\text { not good } \\
\text { because of } \\
\text { tourism. }\end{array}$ & 1.817 & 1.4520 & 2.108 & \\
\hline
\end{tabular}

Source: Prepared by the authors (2019).

more likely to continue to support and encourage tourism (Almeida-García et al., 2016; Ozturk, Ozer, \& Çaliskan, 2015). This result is contrary to Krippendorf's (2001) view that residents having increasingly contrary feelings when perceiving the negative effects of the growth of tourists. The may be because the town is still developing in this direction, and contributes to the results that pointed out Chi, Cai and Li (2017), Marzuki (2012), Andereck and Nyaupane (2011) and Yoon, Gursoy and Chen (2001), who found that residents perceive the positive impacts and benefits gained through tourism more than their negative impacts. This can be seen in the results presented below, analyzing the positive impacts of tourism:

In Table 6, the construct of positive economic impact was measured, which presented an overall average of 5.33. In other words, the level of agreement is high in the statements that tourism attracts more investments to the town and creates job opportunities, which is corroborated by Ozturk, Ozer and Çaliskan (2015). Also, the study by Hartwell et al. (2018) points out that the residents of a destination can feel improvements in the quality of life of the community around the tourist facilities, as they too can benefit from certain attractions, as well as the increase in employment and income opportunities.

The construct Positive cultural and environmental impacts was measured in Table 7. This construct had an overall average of 5.19. As with the previous construct, we can consider that the level of agreement among residents is high when it comes to tourism having a positive impact on local culture and increasing the number of recreational parks and green areas. This last question, about the increase in the number of recreational parks and green areas, is corroborated by the stu- 
Table 6: Averages of the construct Positive economic impacts

\begin{tabular}{l|c|c|c|c}
\hline Variable & $\begin{array}{c}\text { Avera- } \\
\text { ge }\end{array}$ & $\begin{array}{c}\text { Stan- } \\
\text { dard } \\
\text { Devia- } \\
\text { tion (p) }\end{array}$ & $\begin{array}{c}\text { Vari- } \\
\text { ance } \\
\text { (P) }\end{array}$ & $\begin{array}{c}\text { Avera- } \\
\text { ge } \\
\text { dimen- } \\
\text { sion }\end{array}$ \\
\hline $\begin{array}{l}\text { Q12: Tourism } \\
\text { attracts more } \\
\text { investments to } \\
\text { Corupá. }\end{array}$ & 5.330 & 2.2269 & 4,959 & \\
\hline $\begin{array}{l}\text { Q13: Tourism } \\
\text { creates more } \\
\text { job opportuni- } \\
\text { ties in Corupá. }\end{array}$ & 5.330 & 2.1426 & 4,591 & 5.3298 \\
\hline
\end{tabular}

Source: Prepared by the authors (2019).

dy by Yoon, Gursoy and Chen (2001), who found that residents would probably support the development of tourism in their city, particularly due to the consequent investments in infrastructure that benefit the residents as well as the tourists.

Table 8 measures impacts the implementation of a new host and introduced through an overall average size of 4.70. In this construct, we can highlight some issues. The statement "the disused Corupá Seminar is a waste" presented a high average (5.19), as well as issues involving the participation of young people, parents, teachers $(5.46)$ and the community in general $(5,44)$ in the construction of this project. Therefore, it is possible

Table 7: Averages of the construct Positive cultural and environmental impacts

\begin{tabular}{l|c|c|c|c}
\hline \multicolumn{1}{c|}{ Variable } & $\begin{array}{c}\text { Avera- } \\
\text { ge }\end{array}$ & $\begin{array}{c}\text { Stan- } \\
\text { dard } \\
\text { Devia- } \\
\text { tion } \\
\text { (p) }\end{array}$ & $\begin{array}{c}\text { Vari- } \\
\text { ance } \\
\mathbf{( P )}\end{array}$ & $\begin{array}{c}\text { Avera- } \\
\text { ge } \\
\text { dimen- } \\
\text { sion }\end{array}$ \\
\hline $\begin{array}{l}\text { Q14: Tourism } \\
\text { has a positive } \\
\text { impact on the } \\
\text { local culture in } \\
\text { Corupá. }\end{array}$ & 5.335 & 2.0807 & 4,329 & \\
\hline $\begin{array}{l}\text { Q15: Tourism } \\
\text { increases the } \\
\text { number of rec- } \\
\text { reational parks } \\
\text { and green are- } \\
\text { as. }\end{array}$ & 5.047 & 2.1504 & 4.624 & 5.1911 \\
\hline
\end{tabular}

Source: Prepared by the authors (2019).

to note that the population has an interest in participating, since the question "the plan for introducing a new hotel must be transparent and accessible to the population" presented an average of 5.33. The same can be confirmed with the statement "a building of cultural and historical heritage must have its use restricted", which resulted in a low (2.84), i.e., the residents agree with the public and collective use of the space.
Authors such as Gholitabar and Costa (2018) and Ismagilova, Safiullin and Bagautdinova (2014) point out that issues related to the appreciation of local history and culture are receiving more and more prominence. Thus, residents' willingness to give opinions and become in-

Table 8: Averages of the construct Impacts of the implementation of a new hotel

\begin{tabular}{|c|c|c|c|c|}
\hline Variable & $\begin{array}{l}\text { Ave- } \\
\text { rage }\end{array}$ & $\begin{array}{l}\text { Stan- } \\
\text { dard } \\
\text { Devia- } \\
\text { tion } \\
\text { (p) }\end{array}$ & $\begin{array}{l}\text { Vari- } \\
\text { ance } \\
\text { (P) }\end{array}$ & $\begin{array}{c}\text { Ave- } \\
\text { rage } \\
\text { di- } \\
\text { mensi } \\
\text { on }\end{array}$ \\
\hline $\begin{array}{l}\text { Q16: The introduc- } \\
\text { tion of a new hotel in } \\
\text { Corupá should reflect } \\
\text { feedback and com- } \\
\text { ments from resi- } \\
\text { dents. }\end{array}$ & 4.230 & 2.4493 & 5.999 & \multirow{10}{*}{4.7094} \\
\hline $\begin{array}{l}\text { Q17: The plan for } \\
\text { implementing a new } \\
\text { hotel in Corupá } \\
\text { needs to be better } \\
\text { communicated to the } \\
\text { different stakehold- } \\
\text { ers. }\end{array}$ & 4.497 & 2.3303 & 5.430 & \\
\hline $\begin{array}{l}\text { Q18: The disused } \\
\text { Corupá Seminary } \\
\text { building is a waste. }\end{array}$ & 5.194 & 2.4103 & 5.810 & \\
\hline $\begin{array}{l}\text { Q19: Young people, } \\
\text { parents and teachers } \\
\text { should be encour- } \\
\text { aged to participate in } \\
\text { the project by sub- } \\
\text { mitting their ideas. }\end{array}$ & 5.461 & 2.0254 & 4.102 & \\
\hline $\begin{array}{l}\text { Q20: The community } \\
\text { should be encour- } \\
\text { aged to participate in } \\
\text { the project by send- } \\
\text { ing in ideas. }\end{array}$ & 5.445 & 2.0483 & 4,196 & \\
\hline $\begin{array}{l}\text { Q21: Better channels } \\
\text { need to be estab- } \\
\text { lished to involve local } \\
\text { residents in this } \\
\text { change. }\end{array}$ & 5.199 & 2,1181 & 4,487 & \\
\hline $\begin{array}{l}\text { Q22: A building of } \\
\text { cultural and historical } \\
\text { heritage must have } \\
\text { its use restricted. }\end{array}$ & 2.843 & 2.1610 & 4.670 & \\
\hline $\begin{array}{l}\text { Q23: The plan for } \\
\text { implementing a new } \\
\text { means of accommo- } \\
\text { dation must be } \\
\text { transparent and ac- } \\
\text { cessible to the popu- } \\
\text { lation. }\end{array}$ & 5.330 & 2.1743 & 4.727 & \\
\hline $\begin{array}{l}\text { Q24: The historical } \\
\text { significance of the } \\
\text { Seminary must be } \\
\text { assessed by an ex- } \\
\text { pert committee. }\end{array}$ & 4.728 & 2.2732 & 5.168 & \\
\hline $\begin{array}{l}\text { Q25: The design of } \\
\text { the Corupá Seminar } \\
\text { should create a new } \\
\text { image and identity } \\
\text { for the city. }\end{array}$ & 4.168 & 2.3538 & 5.540 & \\
\hline
\end{tabular}

Source: Prepared by the authors (2019). 
volved in the project seems to contribute to and confirm these analyzes, since, as mentioned by the authors, the community is participating in the construction of its own history. Ozturk, Ozer and Çaliskan (2015) corroborate these results when they point out that to reduce the negative impacts caused by tourist activities in the life of the community, it is necessary to develop policies and regulations to protect the city's natural, cultural and historical heritage.

Xie and Shi (2018) also corroborate our results; in addition to nostalgia for the heritage, and its preservation, it is possible to develop a tourism project with commercial goals. In the results found, we can see that residents are favorable towards tourism, and are positively positioned to take part in the project to transform the seminary, to enhance the development of tourism in Corupá. As stated by Lakatos (2017) and Ismagilova, Safiullin and Bagautdinova (2014), revitalization can bring benefits and opportunities to the town.
Finally, in Table 9 below, the mean scores for each dimension are cross-checked with the characteristics of the survey respondents' profile.

Regarding the respondents' sex, the differences in means are relatively small. It is noted, above all, that in the constructs that measure negative impacts as a whole, men have a more positive perception than women, i.e., they believe that tourism does not have as many negative impacts.

Regarding the respondents' age groups, we found that most negative perceptions were among the "under 15 years" age group, as these respondents were more aware of the negative cultural and environmental impacts, and also the negative economic impacts, as well as showing the highest average for positive impacts. People aged 56 and over were also the group that most perceived the positive cultural, environmental and economic impacts of tourism.

Table 9: Intersections of the mean dimensions with profile characteristics

\begin{tabular}{|c|c|c|c|c|c|c|c|}
\hline \multicolumn{2}{|c|}{ Variable } & \multirow{2}{*}{$\begin{array}{c}\begin{array}{c}\text { Negative cultu- } \\
\text { ral and environ- } \\
\text { mental impact }\end{array} \\
1.8459\end{array}$} & \multirow{2}{*}{$\begin{array}{l}\text { Factor } \\
1.8818\end{array}$} & \multirow{2}{*}{$\begin{array}{c}\begin{array}{c}\text { Negative } \\
\text { economic } \\
\text { impacts }\end{array} \\
2.3041\end{array}$} & \multirow{2}{*}{$\begin{array}{c}\begin{array}{c}\text { Positive } \\
\text { economic } \\
\text { impacts }\end{array} \\
5.5000\end{array}$} & \multirow{2}{*}{$\begin{array}{c}\begin{array}{c}\text { Positive cultu- } \\
\text { ral and envi- } \\
\text { ronmental } \\
\text { impacts }\end{array} \\
5.1554\end{array}$} & \multirow{2}{*}{$\begin{array}{c}\text { Implemen- } \\
\text { tation of a } \\
\text { new hotel }\end{array}$} \\
\hline \multirow{3}{*}{ Sex } & Male & & & & & & \\
\hline & Female & 2.0821 & 1.9679 & 2.5299 & 5.2222 & 5.2137 & 4.6735 \\
\hline & Overall average & 1.9906 & 1.9346 & 2.4424 & 5.3298 & 5.1911 & 4.7094 \\
\hline \multirow{6}{*}{$\begin{array}{l}\text { Age } \\
\text { Range }\end{array}$} & Under 15 years & 3.4000 & 1.0000 & 4,0000 & 7.0000 & 7.0000 & 5.0000 \\
\hline & 15 to 24 years & 1.8238 & 1.9464 & 2.4167 & 5.5357 & 5.5595 & 4.8905 \\
\hline & 25 to 39 years & 2.1172 & 2.0402 & 2.5805 & 5.1149 & 5.0057 & 4.6851 \\
\hline & 40 to 55 years & 2.0255 & 1.9096 & 2.2766 & 5.1915 & 4.9468 & 4.5149 \\
\hline & 56 years or older & 1.4857 & 1.3929 & 2.1071 & 6.3929 & 5.9286 & 4.9500 \\
\hline & Overall average & 1.9906 & 1.9346 & 2.4424 & 5.3298 & 5.1911 & 4.7094 \\
\hline \multirow{5}{*}{$\begin{array}{l}\text { Mari- } \\
\text { tal } \\
\text { status }\end{array}$} & Single & 1.9655 & 1.8879 & 2.4052 & 5.5862 & 5.4397 & 4.8966 \\
\hline & $\begin{array}{l}\text { Married/stable } \\
\text { relationship }\end{array}$ & 2.0295 & 1.9877 & 2.4877 & 5.1803 & 5.0656 & 4.6295 \\
\hline & $\begin{array}{l}\text { Separated/ } \\
\text { Divorced }\end{array}$ & 1.4000 & 1.7188 & 2.0000 & 5,7500 & 5.5625 & 4.2000 \\
\hline & Widower & 2.4667 & 1.2500 & 2.5000 & 5.3333 & 4.5000 & 5.7000 \\
\hline & Overall average & 1.9906 & 1.9346 & 2.4424 & 5.3298 & 5.1911 & 4.7094 \\
\hline \multirow{7}{*}{$\begin{array}{l}\text { Time } \\
\text { of } \\
\text { resi- } \\
\text { dence } \\
\text { in } \\
\text { Corup } \\
\text { á }\end{array}$} & Less than 5 years & 1.8500 & 1.6875 & 2.3750 & 5,7500 & 5.4167 & 5.4000 \\
\hline & 5 to 9 years & 2.2667 & 2.3889 & 2.3889 & 5.3056 & 5.2500 & 5.0889 \\
\hline & 10 to 14 years & 2.4857 & 2.3036 & 2.8214 & 5.2857 & 5.3929 & 5.0286 \\
\hline & 15 to 19 years & 1.9765 & 1.9412 & 2.3529 & 4.7941 & 4.8235 & 4.3824 \\
\hline & 20 to 24 years & 1.8171 & 1.8714 & 2.2429 & 5.6714 & 5.6714 & 4.7143 \\
\hline & 25 years or more & 1.9495 & 1.8474 & 2.4947 & 5.2579 & 5.0105 & 4.5600 \\
\hline & Overall average & 1.9906 & 1.9346 & 2.4424 & 5.3298 & 5.1911 & 4.7094 \\
\hline
\end{tabular}

Source: Prepared by the authors (2019). 
Regarding marital status, the differences are also not significant. In general, those were "widowed" were slightly more concerned with the negative cultural and environmental impacts and the negative economic impacts, while at the same time, they were the least concerned with the crime factor.

Finally, regarding the length of time living in the town of Corupá, it was found that residents who had lived there for between 5 and 14 years were the group who most perceive the negative impacts of tourism. Those who had lived there for between 15 and 19 years were the group ones who least perceived the positive impacts. The results are contrary to those of AlmeidaGarcía et al. (2016), who report that people who have lived in a destination for more than ten years will also perceive tourism in a more negative way.

\section{FINAL CONSIDERATIONS}

This study seeks to contribute, in a theoretical and empirical way, to discussions on the development of tourism in the town of Corupá, where the Catholic Seminary is located, a historical a cultural heritage site of the town. There are plans underway, by the Catholic church, to transform this building into a hotel. This study investigates the level of acceptance of the local community for the development of the project and local tourism, since, as reported by Xie and Shi (2018), the local community has a major influence in revitalizing and transforming a space considered heritage. Besides promoting the place as a tourist destination, the transformation of these spaces also favors the preservation of the built environment (Timothy \& Teye, 2009).

It is notable that among the main results found, that the residents of Corupá, in general, do not feel the negative impacts of tourism, whether these be related to the cultural, environmental, economic impact or even increased crime. However, according to studies by Almeida-García et al. (2016) and Ozturk, Ozer \& Çaliskan (2015), it is important that the local residents be involved in the decision-making, as this will make them more likely to accept the inconveniences that tourism brings. On the other hand, the residents were favorable towards tourism, perceiving the positive impacts. This result is somewhat positive, as it demonstrates the interest in the development of tourism in the municipality.

Andereck and Nyaupane (2011) point out that residents who personally benefit more from tourism have positive attitudes towards tourism. Hartwell et al. (2018), reports that the residents of a destination can feel how much tourism affects the life of the community, through improvements in quality of life, tourist facilities, attractions and events that residents can also benefit from, in addition to increase employment and income opportunities. Therefore, we see that in the town of Corupá, the development of tourism has great potential. The negative impacts were felt to be minor, which the positive impacts were appreciated by the residents. Therefore, as Chi, Cai and Li (2017) had already observed, residents accept the growth of tourism because they are aware of the benefits it brings to their town or city.

According to (Bimonte \& Faralla, 2016). it is very important to understand the relationship between tourism and residents for the success of tourism development in a destination. This echoes the result of AlmeidaGarcía et al. (2016), and the results found in the last construct of this study, were we can also see the importance of involving residents in decisions related to tourism development, so that they feel part of the process. Therefore, as mentioned by Ozturk, Ozer and Çaliskan (2015), tourism planners should take into consideration the residents' concerns about the impacts that tourism can bring to their areas.

Another relevant result was related to the analysis of the introduction of a new hotel. It was found that the community has a desire to participate, contribute and give its opinions to the project, collaborating with the findings of Ozturk, Ozer and Çaliskan (2015), who report that two-way communication between residents and policy makers transmits useful and effective plans in the decision-making process related to tourism.

The local community of Corupá believes that the structure of the disused Corupá Seminary is a waste, and that a building of such cultural and historical importance should not have its use restricted. This is in line with the view of Lakatos (2017) and Ismagilova, Safiullin and Bagautdinova (2014), that revitalizing a space like the seminary can bring benefits and opportunities for the town. Finally, corroborating the finding of Santos and Cavalcanti Neto (2008) on the revitalization of religious buildings to serve as hotels, this is seen as positive, given that the functions of the seminary and a hotel are similar, with both providing accommodation, and spaces in which to eat, sleep, stroll and socialize.

One of the limitations of this study is its sample size, as for some authors, it is considered too small. Nevertheless, the reliability indexes of the construct guarantee the importance of the results. As a suggestion for future studies, we suggest qualitative research on the perceptions of the community, and an in-depth analysis of religion in relation to the impact of tourism and support from residents, especially in the case of a church building that will have an impact on religious tourism in the region. We also suggest an in-depth analysis of the transformation of the Corupá Seminary, and the limitations to transforming it into a hotel in the town. 


\section{REFERENCES}

Almeida-García, F., Peláez-Fernández, M. Á., Balbuena-Vázquez, A., \& Cortés-Macias, R. (2016). Residents' perceptions of tourism development in Benalmádena (Spain). Tourism Management, 54, 259-274. Retrieved from: https:// www.sciencedirect.com/science/article/abs/pii/ S026151771530042X

Andereck, KL, \& Nyaupane, GP (2011). Exploring the nature of tourism and quality of life perceptions among residents. Journal of Travel research, 50 (3), 248260. Retrieved from: https://journals.sagepub.com/doi/ abs $/ 10.1177 / 0047287510362918$

Aspres, AL (2017). Monuments converted into hotels: the sacrifice of architectural memory. The case of Santo Estevo de Ribas de Sil. PASOS. Revista de Turismo y Patrimonio Cultural, 15 (3), 673-685. Retrieved from: https:// www.redalyc.org/pdf/881/88151417011.pdf

Aulet, S., Mundet, L., \& Vidal, D. (2017). Monasteries and tourism: interpreting the sacred landscape through gastronomy. Brazilian Journal of Tourism Research, $11(1)$, 175196. Retrieved from: https://www.scielo.br/scielo.php? pid=S1982-61252017000100175\&script=sci_arttext

Bimonte, S., \& Faralla, V. (2016). Does residents' perceived life satisfaction vary with tourist season? A two-step survey in a Mediterranean destination. Tourism Management, 55, 199-208. Retrieved from: https://www.sciencedirect.com/ science/article/abs/pii/S0261517716300231

Björk, P., \& Sthapit, E. (2017). Well-Being of Locals, Tourist Experiences and Destination Competitiveness. In Co-Creation and Well-Being in Tourism (pp. 149-162). Springer, Cham. Retrieved from: https://link.springer.com/ chapter/10.1007/978-3-319-44108-5_12

Chi, CGQ, Cai, R., \& Li, Y. (2017). Factors influencing residents subjective well-being at World Heritage Sites. Tourism Management, 63, 209-222. Retrieved from: https:// www.sciencedirect.com/science/article/abs/pii/ S0261517717301413

Clavé, SA, Reverté, FG, \& Tabales, AF (2009). Introducing the tourist space. UOC Universitat Oberta de Catalunya. Retrieved from: annotation/7f8debd6e78bf45c3754f7d1d06aa501/592945/ PID_00141264/PID_00141264.html

de la Torre, GMV, Naranjo, LMP, \& Cárdenas, RM (2012). Stages of the life cycle in the development of religious tourism: a comparison of case studies. Cuadernos de turismo, (30), 241-266. Retrieved from: https://revistas.um.es/turismo/ article/view/160741

Ferreira, E., \& Santos, SRD (2010). Tourist route through the Catholic churches of the historic center of São Luís (MA). Mercosur Tourism Research Seminar, 6, 0117. Retrieved from: https://www.ucs.br/ucs/eventos/ seminarios semintur/semin tur 6/arquivos/07/Roteiro\% 20Turistico\%20pelas\%20lgrejas\%20Catolicas\%20do\%

\section{Centro\%20Historico\%20de\%20Sao.pdf}

Galeotti, G. (2016). Elements for impact assessment of cultural heritage and community well-being. A qualitative study on Casentino's Eco-museum. II Capitale Culturale. Studies on the Value of Cultural Heritage, (14), 913-943. Retrieved from: http://riviste.unimc.it/index.php/cap-cult/article/ view/1457

Gholitabar, S., \& Costa, C. (2018). Assessing patrons' satisfaction with the cultural heritage attribute (accommodation) in the historical city "Isfahan, Iran" (Abbasi Hotel). Revista Turismo \& Desenvolvimento (RT\&D) / Journal of Tourism \& Development, (29). Retrieved from: https:// web.a.ebscohost.com/abstract?

di-

rect=true \&profile=ehost \&scope=site\&authtype=crawler $\&$ jr $\mathrm{nl}=16459261 \& \mathrm{AN}=130523310 \& \mathrm{~h}=98 \mathrm{GEaYT9OS4Bh \%}$ 2bu7D1fzHnK7SbpsF7WpF\%

2fK0xocAmVGU4P6EIDX97cUVaRgh\%2baiTJ20fOMTk722\% 2fPxT1N8uA8g\%3d\%

$3 \mathrm{~d} \& \mathrm{crl}=\mathrm{c} \&$ resultNs=AdminWebAuth\&resultLocal=ErrCrINot Auth\&crlhashurl = login.aspx\% 3fdirect\% 3dtrue\% 26profile\% 3dehost\% 26scope\% 3dsite\% 26authtype\% 3dcrawler\% 26jrnl\% 3d16459261\% 26AN\% 3d130523310

Gursoy, D., \& Rutherford, DG (2004). Host attitudes toward tourism: An improved structural model. Annals of tourism Research, 31 (3), 495-516. Retrieved from: https:// www.sciencedirect.com/science/article/abs/pii/ S0160738304000362

HAIR JR., JF et al. Multivariate data analysis. 5. ed. Englewood Cliffs, NJ: Prentice-Hall, 1998.

Hartwell, H., Fyall, A., Willis, C., Page, S., Ladkin, A., \& Hemingway, A. (2018). Progress in tourism and destination wellbeing research. Current Issues in Tourism, $21(16)$, 18301892. Retrieved from: https://www.tandfonline.com/doi/ abs/10.1080/13683500.2016.1223609

Ismagilova, GN, Safiullin, LN, \& Bagautdinova, NG (2014). Tourism development in region based on historical heritage. Life Science Journal, 11 (6s), 363-367. Retrieved from: http:// www.lifesciencesite.com/lsj/ life1106s/074_24314life1106s14_363_367.pdf

lapichino, DA (2010). Characteristics of Personality and Motivation of Tourists Alla Scelta Del Viaggio of Tipo Religioso. (Doctoral thesis). Tourism Course, Dipartimento di Metodi Quantitativi Per Le Scienze Umane, Università Degli Studi di Palermo, Palermo. Retrieved from: https:// iris.unipa.it/handle/10447/95179\#.X2AUH2hKjIU

IBGE CITIES. Retrieved from: https://cidades.ibge.gov.br/

Ivlevs, A. (2017). Happy hosts? International tourist arrivals and residents' subjective well-being in Europe. Journal of Travel Research, 56 (5), 599-612. Retrieved from: https:// journals.sagepub.com/doi/ abs $/ 10.1177 / 0047287516662353$

Juravle, AI, \& Spãtaru, GC (2016). Religious Marketing: Theoretical articles. SEA - Practical Application of Science, v. IV, Issue 2 (11).

Ko, DW, \& Stewart, WP (2002). A structural equation model of residents' attitudes for tourism development. Tourism 
management, 23 (5), 521-530. Retrieved from: https:// www.sciencedirect.com/science/article/abs/pii/ S0261517702000067

Krippendorf, J. (1989). Sociology of tourism: for a new understanding of leisure and travel. Rio de Janeiro: Brazilian Civilization.

Lakatos, AE (2017). The Revitalization of Cities through Conversion. Cultures of Communication - Cultures de la communication, 2 (1), 99-116. Retrieved from: https:// www.ceeol.com/search/article-detail?id=700576

Marzuki, A. (2012). Local residents' perceptions towards economic impacts of tourism development in Phuket. Tourize: međunarodni znanstveno-stručni časopis, 60 (2), 199212. Retrieved from: https://hrcak.srce.hr/index.php? show=clanak\&id_clanak_jezik=125947

Milito, M., Marques, S. and Alexandre, M. 2013. Resident's perception of tourism and mega-events: bibliometric analysis of international and Latin American journals. Revista Turismo em Análise. 24, 3, 482-502. Retrieved from: http:// www.periodicos.usp.br/rta/article/view/79784

Mirrado, JMC (2016). The meanings of reuse: from the convent to the non-convent Mosteiro de Odivelas, S. Dinis and S. Bernardo (Doctoral Thesis). Lusophone University of Humanities and Technologies, Department of Architecture. Retrieved from: https://recil.grupolusofona.pt/ handle/10437/7811

$\mathrm{Ng}, \mathrm{SL}$, \& Feng, X. (2020). Residents' sense of place, involvement, attitude, and support for tourism: a case study of Daming Palace, a Cultural World Heritage Site. Asian Geographer, 1 -19. Retrieved from: https://www.tandfonline.com/doi/ abs/10.1080/10225706.2020.1729212

Ozturk, AB, Ozer, O., \& Caliskan, U. (2015). The relationship between local residents' perceptions of tourism and their happiness: a case of Kusadasi, Turkey. Tourism Review. Retrieved from: https://www.emerald.com/insight/ content/doi/10.1108/TR-09-2014-0053/full/html

Rasoolimanesh, SM, Taheri, B., Gannon, M., Vafaei-Zadeh, A., \& Hanifah, H. (2019). Does living in the vicinity of heritage tourism sites influence residents' perceptions and attitudes?. Journal of Sustainable Tourism, 27 (9), 12951317. Retrieved from: https://www.tandfonline.com/doi/ abs/10.1080/09669582.2019.1618863

Ryu, K., Lehto, XY, Gordon, SE, \& Fu, X. (2018). Compelling brand storytelling for luxury hotels. International Journal of Hospitality Management, 74, 22-29. Retrieved from: https:// www.cabdirect.org/cabdirect/abstract/20183326746

Santos, JR, \& Cavalcanti Neto, JR (2008). Pousada do Convento do Carmo in Salvador da Bahia: The Experience of Pousadas de Portugal in the Rehabilitation of Monastic Buildings for Tourist Inns. Anais do ArquiMemória 3 - National Meeting of Architects on the Preservation of Built Heritage - Built Heritage: Social Function, Integration and Participation, Salvador da Bahia, Institute of Architects of Brazil. Retrieved from: https://www.academia.edu/8597298/ Pousa-

da_do_Conmoento_do_Carmo_em_Salvador_da_Bahia_A Experi\%C3\%

ÁAncia_das_Pousadas_de_Portugal_na_Reabilita\%C3\%

\section{A7\%C3\%A3o_de_Edif\%A3}

Sebrae SC. (2018). Cultural tourism: opportunities for strengthening tourism in Santa Catarina. [Webpage]. Retrieved November 2, 2018. Retrieved from: https://sis.sebraesc.com.br/produtos/relatorios-de-inteligencia/turismocultural/5b5f15d607c9621800ec002.

Corupá Seminar. (2018). History. [Webpage]. Retrieved November 2 , 2018. Retrieved from: http:// www.seminariodecorupa.com.br/historia/.

Stylidis, D., Biran, A., Sit, J., \& Szivas, EM (2014). Residents 'support for tourism development: The role of residents' place image and perceived tourism impacts. Tourism Management, 45, 260-274. Retrieved from: https:// www.sciencedirect.com/science/article/abs/pii/ S0261517714000995

Tendeiro, ILGS (2010). The Santo Antônio de Lisboa church and the Italian religious tourism. (Masters dissertation). Tourism, Specialization in Strategic Management of Tourist Destinations - Escola Superior de Hotelaria e Turismo do Estoril. Retrieved from: http://comum.rcaap.pt/ handle/10400.26/2416

Timothy, D., \& Teye, V. (2009). Tourism and the lodging sector. Routledge. Retrieved from: https:// books.google.com.br/books? $\mathrm{hl}=\mathrm{en} \& \mid \mathrm{r}=\& \mathrm{id}=\mathrm{v} 8 \mathrm{ssBgAAQBAJ} \& \mathrm{oi}=\mathrm{fnd} \& \mathrm{pg}=\mathrm{PP} 1 \& \mathrm{dq}=$ Timoth $y,+D .,+\% 26+$ Teye, + V.+(2009) . + Tourism + and + the + lodging + sector. + Routledge. $\&$ Ots $=3$ Lv8FrwiSr $\&$ sig $=$ ANZf7RJWQ525zXUkUZs6RPPTPIY \# $v=$ onepage $\& \mathrm{q}=\mathrm{Ti}-$ mothy\% 2C\% 20\% 26\% 20Teye\% 2C\% 20V.\% 20 (2009). \% 20Tourism\% 20and\% 20the\% 20lodging\% 20sector.\% 20Routledge. \& $\mathrm{F}=$ false

Tricárico, LT, \& Capra, RC (2015). Justification of pleasure and emotion in the current hospitality according to Maslow. TURYDES, 8 (18).

Corupá Tourism. (2018). About the city. [Webpage]. Retrieved November 2, 2018. Retrieved from: https:// turismo.corupa.sc.gov.br/sobre-a-cidade.

Woo, E., Kim, H., \& Uysal, M. (2015). Life satisfaction and support for tourism development. Annals of tourism research, 50, 84-97. Retrieved from: https://www.sciencedirect.com/ science/article/abs/pii/S0160738314001406

Xie, PF, \& Shi, WL (2018). Authenticating a heritage hotel: cocreating a new identity. Journal of Heritage Tourism, 14 (1), 67-80. Retrieved from: https://www.tandfonline.com/doi/ abs/10.1080/1743873X.2018.1465062

Yoon, Y., Gursoy, D., \& Chen, JS (2001). Validating a tourism development theory with structural equation modeling. Tourism management, 22 (4), 363-372. Retrieved from: https://www.sciencedirect.com/science/article/abs/ pii/S0261517700000625 OLIVEIRA, Marlene de. Organização e execução de eventos. Curitiba: e-Tec/MEC, 2013. 